\title{
THE PROGRESS OF E-GOVERNMENT BENCHMARKING FRAMEWORKS' STRUCTURE IN THE WORLD
}

\author{
[Vývoj struktury hodnotících rámců pro měření rozvoje e-governmentu \\ ve světě]
}

\author{
Renáta Máchová ${ }^{1}$, Martin Lněnička ${ }^{2}$ \\ ${ }^{1}$ Univerzita Pardubice, Fakulta ekonomicko-správní, Studentská 84, 53210 Pardubice \\ Email:renata.machova@upce.cz \\ ${ }^{2}$ Univerzita Pardubice, Fakulta ekonomicko-správní, Studentská 84, 53210 Pardubice \\ Email:martin.Inenicka@gmail.com
}

\begin{abstract}
E-government benchmarking frameworks are important as they guide countries' focus of their efforts to develop information and communication policies and allocating resources to implement these strategies. With the decrease of importance of basic information society indicators in the past and use of new technologies and trends, new criteria and approaches needed to be introduced in measuring e-government development. Therefore, the existing frameworks should be updated and reframed. The main aim of this paper is to examine a progress in the structure of these benchmarking frameworks and propose a new benchmarking framework, which uses modern technologies such as cloud computing, open data, big data, social media and e-participation. It focuses on this new set of domains of activities and assesses many of them. Methods of decomposition and aggregation are used.
\end{abstract}

Keywords: benchmarking framework, decomposition, e-government, indices.

JEL classification: C43, H83, L86

Doručeno redakci: 9.2.2015; Recenzováno: 8.3.2015; 8.4.2015; Schváleno k publikování: 27.5.2015

\section{Úvod}

V posledních 10-15 letech vzniklo ve světě množství hodnotících rámců se zaměrením na porovnávání vývoje elektronické veřejné správy (e-governmentu) ve vybraných zemích světa. Tyto rámce jsou prezentovány ve formě periodických zpráv, které jsou vydávány zpravidla nadnárodními institucemi nebo univerzitami, a jejich výstupem je pak většinou index nebo pořadí zemí na základě definovaných oblastí. Každý index se může skládat i z několika sub-indexů, resp. komponent, které lze rovněž považovat za samostatné ukazatele vývoje v oblasti e-governmentu. I tyto komponenty mají své pořadí nejlepších zemí, a proto jsou jednotlivé zprávy prezentovány jako komplexní přehled ukazatelů vývoje $\mathrm{v}$ dané oblasti. Na nejnižší úrovni jsou jednotlivé hodnotící otázky a atributy. Hlavní rozdíl mezi hodnotícími otázkami a atributy je ten, že otázky jsou definovány danou organizací a vycházejí zpravidla z jejího dotazníkového šetření, zatímco atributy jsou dány metodikou nadnárodních institucí, které se zaměřují na danou oblast. Není proto neobvyklé, že některé atributy se v různých rámcích opakují nebo některé rámce jsou tvořeny výstupy jiných rámců, tzn., že jeden index je často sub-indexem jiného indexu. Toto vše bude rovněž zmíněno dále $v$ tomto př́íspěvku.

S rozvojem moderních informačních a komunikačních technologií (ICT) je však nutné tyto rámce aktualizovat $\mathrm{s}$ ohledem na rostoucí význam těchto technologií pro veřejnou správu, resp. její konzumenty, tzn. občany a podniky. Cílem tohoto př́spěvku je tak porovnání vývoje struktury vybraných rámců a poté identifikace základních oblastí a hodnotících kriterií, která budou sloužit pro návrh vlastního hodnotícího rámce s ohledem na aktuální trendy ve veřejné správě. Za tímto účelem jsou využity metody dekompozice, agregace, komparace hodnotících rámců a zařazení atributů do skupin. Vlastní rámec je zaměřen na úroveň Evropské unie (EU), 
kde lze díky společným nařízením a zákonům na nadnárodní úrovni zajistit větší kompaktnost tohoto nově navrženého hodnotícího rámce.

\section{Rámce pro hodnocení vývoje e-governmentu}

Některé atributy v hodnotících rámcích jsou tedy založeny na měřitelných charakteristikách, tzv. hard data, další pak využívají různé subjektivní ukazatele získané z dotazníkových šetření nebo hlasování expertů jak podrobně uvádí např. Rorissa et al. (2011). Vlastní metodika výpočtu daného indexu může být opět velmi rozdílná. Zpravidla je nutné data standardizovat, pokud pochází z různých zdrojů, určit interval, na kterém budou výsledky prezentovány a nakonec vypočítat celkový index s ohledem na váhy atributů.

Jednotlivé indexy lze rozdělit přibližně do dvou skupin. První tvoří globální indexy, které hodnotí situaci ve většině států světa a struktura těchto indexů se mění pouze minimálně. Sem patř́ E-Government Development Index (EGDI) a E-Participation Index (EPI) od Organizace spojených národů (OSN), Economist Intelligence Unit (EIU) index, ICT Development Index (IDI) od Mezinárodní telekomunikační unie (International Telecommunication Union, ITU), Networked Readiness Index (NRI), který je vydáván Světovým ekonomickým fórem (World Economic Forum, WEF) nebo The Brown University (TBR) index. Druhou skupinu pak tvoří specializované indexy, které se snaží hodnotit vývoj s ohledem na aktuální trendy v ICT nebo se zaměřují na vybrané oblasti ve světě, např. pouze vyspělé státy světa, které mají zdroje pro využívání moderních ICT. Sem patří série zpráv od EU s názvem E-government Benchmark Report (EUBR) a Waseda index. Po roce 2010 začaly vznikat i další specializované indexy jako např. Business Software Alliance (BSA) Global Cloud Computing Scorecard, Cloud Readiness Index (CRI), který vydává Asia Cloud Computing Association (ACCA), Web Index od World Wide Web Foundation (W3F) nebo také Global Open Data Index (GODI) od Open Knowledge Foundation (OKF). Tabulka 1 zachycuje přehled vybraných indexů, když porovnává především časové rozpětí, které je indexy pokryto, a počet hodnocených zemí.

Tabulka 1: Porovnání vzniku a vývoje vybraných indexů

\begin{tabular}{|c|c|c|c|c|c|c|}
\hline \multirow{2}{*}{ Index } & Vydavatel & $\begin{array}{c}\text { Vydání } \\
\text { první } \\
\text { zprávy }\end{array}$ & $\begin{array}{c}\text { Poslední } \\
\text { zpráva }\end{array}$ & $\begin{array}{c}\text { Počet } \\
\text { zpráv }\end{array}$ & $\begin{array}{c}\text { Počet hodnocených zemí } \\
\text { zprávě }\end{array}$ & $\begin{array}{c}\text { V poslední } \\
\text { zprávě }\end{array}$ \\
\hline BSA index & BSA & 2012 & 2013 & 2 & 24 & 24 \\
\hline CRI & ACCA & 2011 & 2014 & 3 & 14 & 14 \\
\hline EGDI & OSN & 2003 & 2014 & 7 & 191 & 193 \\
\hline EIU index & The Economist & 2000 & 2010 & 11 & 60 & 70 \\
\hline EPI & OSN & 2003 & 2014 & 7 & 191 & 192 \\
\hline EUBR & EU & 2001 & 2014 & 11 & 17 & 33 \\
\hline GODI & OKF & 2013 & 2014 & 2 & 60 & 97 \\
\hline IDI & ITU & 2009 & 2014 & 6 & 154 & 166 \\
\hline NRI & WEF & 2002 & 2014 & 13 & 75 & 148 \\
\hline TBR index & $\begin{array}{c}\text { Brown } \\
\text { University }\end{array}$ & 2001 & 2007 & 7 & 198 & 198 \\
\hline Waseda index & $\begin{array}{c}\text { Waseda } \\
\text { University }\end{array}$ & 2005 & 2014 & 10 & 23 & 61 \\
\hline Web index & W3F & 2012 & 2014 & 3 & 61 & 86 \\
\hline
\end{tabular}

Zdroj: vlastní zpracování

\subsection{Popis vzniku a vývoje vybraných indexů první skupiny}

V tomto příspěvku nebudou blíže porovnány dva indexy, které již delší dobu nejsou aktuální, nicméně mají stále své významné místo v oblasti hodnocení vývoje e-governmentu ve světě. 
Prvním je EIU index, který vycházel mezi lety 2000 a 2010. Do roku 2009 pod názvem E-readiness rankings, v roce 2010 pak pod názvem Digital economy rankings. V letech 2011 a 2012 byly ještě vydány související zprávy s názvem The government broadband report, kde byl představen index zaměřený na kvalitu vysokorychlostního připojení. Nicméně počet zde hodnocených zemí klesl z více jak $30 \mathrm{v}$ roce 2011 na $16 \mathrm{v}$ roce 2012 a na počátku roku 2015 již nebyla dostupná žádná aktuální zpráva o stavu e-governmentu od EIU. Brown University vydala mezi lety 2000-2007 celkem 7 zpráv pod názvem Global E-Government Report, kde hodnotila zejména webové stránky a nabídku elektronických služeb ve vybraných zemích světa. Ani v tomto př́padě již nevzniklo pokračování. Dále nebudou podrobně porovnávány ani zprávy EUBR. Hlavním důvodem je, že jsou navázány na hodnotící rámec, který je platný zpravidla 3 roky a pak je vytvořen rámec zcela nový, takže není možné jednoduše porovnávat vývoj v čase. První zpráva vyšla v roce 2001 pro 17 evropských zemí. Poslední zpráva je pak z roku 2014 a hodnotí 33 zemí (EU28, Island, Norsko, Srbsko, Švýcarsko a Turecko) na základě hodnotícího rámce pro 2012-2015. Výstupy těchto zpráv jsou zpravidla ve formě grafů a skupin hodnocených zemí na základě dat získaných výhradně z vlastních průzkumů.

Vývoj struktury indexů patřících do první skupiny je zachycen v Tabulce 2. Popis struktury, jednotlivých komponent a atributů je u indexů EGDI a IDI zobrazen do všech detailů, u NRI jsou $\mathrm{z}$ důvodu přehlednosti uvedeny jen komponenty první a druhé úrovně. Tento index je víceúrovňový a značně rozsáhlý, když v první zprávě z roku 2002 byl tvořen celkem 75 atributy a v poslední dostupné zprávě z roku 2014 pouze 54 atributy s tím, že během let existence tohoto indexu bylo hodnoceno ještě asi 20 dalších atributů. Index EPI se během své existence sice zdánlivě nezměnil, nicméně jeho jednotlivé komponenty jsou v každém vydání hodnoceny na základě aktualizovaných otázek, které však OSN podrobně nezveřejňuje, jen zmíní výčet nových oblastí a změn. Tento index je zároveň nejčastěji jako sub-index také $\mathrm{v}$ jiných indexech, např. NRI nebo Waseda index.

Tabulka 2: Porovnání struktury první skupiny vybraných indexů v průběhu let

\begin{tabular}{|c|c|c|c|}
\hline Index & Struktura a sledované komponenty daného indexu & Pokrytí & Váha \\
\hline \multirow[t]{22}{*}{ EGDI } & 1. Web Measure/Online Service Index & $2003-2014$ & $1 / 3$ \\
\hline & Emerging presence & $2003-2014$ & $1 / 5$ (2003-2008), 1/4 (2010-2014) \\
\hline & Enhanced presence & $2003-2014$ & $1 / 5(2003-2008), 1 / 4(2010-2014)$ \\
\hline & Interactive presence & $2003-2008$ & $1 / 5$ \\
\hline & Transactional presence & $2003-2014$ & $1 / 5(2003-2008), 1 / 4(2010-2014)$ \\
\hline & Networked presence & $2003-2010$ & $1 / 5(2003-2008), 1 / 4(2010)$ \\
\hline & Connected presence & $2012-2014$ & $1 / 4(2012-2014)$ \\
\hline & 2. Technological/Telecommunication Infrastructure Index & $2003-2014$ & $1 / 3$ \\
\hline & PCs per 1000 persons/100 inhabitants & $2003-2010$ & $1 / 5$ \\
\hline & Internet users per 1000 persons $/ 100$ inhabitants & $2003-2014$ & $1 / 5$ \\
\hline & Fixed telephone lines per 1000 persons $/ 100$ inhabitants & $2003-2014$ & $1 / 5$ \\
\hline & Mobile telephones per 1,000 persons/100 inhabitants & $2003-2014$ & $1 / 10(2003-2005), 1 / 5(2008-2014)$ \\
\hline & On-line population per 1000 persons & $2003-2005$ & $1 / 5$ \\
\hline & TVs per 1000 persons & $2003-2005$ & $1 / 10$ \\
\hline & Fixed broadband subscriptions per 100 inhabitants & $2008-2014$ & $1 / 5$ \\
\hline & Fixed Internet subscriptions per 100 inhabitants & 2012 & $1 / 5$ \\
\hline & Wireless broadband subscriptions per 100 inhabitants & 2014 & $1 / 5$ \\
\hline & 3. Human Capital Index & $2003-2014$ & $1 / 3$ \\
\hline & Adult literacy rate & $2003-2014$ & $2 / 3(2003-2012), 1 / 3(2014)$ \\
\hline & The combined gross enrolment ratio & $2003-2014$ & $1 / 3(2003-2012), 2 / 9(2014)$ \\
\hline & Expected years of schooling & 2014 & $2 / 9$ \\
\hline & Mean years of schooling & 2014 & $2 / 9$ \\
\hline \multirow[t]{3}{*}{ EPI } & 1. E-information & $2003-2014$ & $1 / 3$ \\
\hline & 2. E-consultation & $2003-2014$ & $1 / 3$ \\
\hline & 3. E-decision-making & $2003-2014$ & $1 / 3$ \\
\hline \multirow[t]{2}{*}{ IDI } & 1. Access sub-index & $2009-2014$ & $2 / 5$ \\
\hline & Fixed telephone lines/subscriptions per 100 inhabitants & $2009-2014$ & $1 / 5$ \\
\hline
\end{tabular}




\begin{tabular}{|c|c|c|c|}
\hline & Mobile telephone subscriptions per 100 inhabitants & $2009-2014$ & $1 / 5$ \\
\hline & International Internet Bandwidth (bit/s) per Internet user & $2009-2014$ & $1 / 5$ \\
\hline & Percentage of households with a computer & $2009-2014$ & $1 / 5$ \\
\hline & Percentage of households with Internet access & $2009-2014$ & $1 / 5$ \\
\hline & 2. Use sub-index & $2009-2014$ & $2 / 5$ \\
\hline & Internet users per 100 inhabitants/Percentage of users & $2009-2014$ & $1 / 3$ \\
\hline & Fixed (wired) broadband subscriptions per 100 inhab. & $2009-2014$ & $1 / 3$ \\
\hline & Mobile broadband subscriptions per 100 inhabitants & $2009-2012$ & $1 / 3$ \\
\hline & Wireless broadband subscriptions per 100 inhabitants & $2013-2014$ & $1 / 3$ \\
\hline & 3. Skills sub-index & $2009-2014$ & $1 / 5$ \\
\hline & Adult literacy rate & $2009-2014$ & $1 / 3$ \\
\hline & Secondary gross enrolment ratio & $2009-2014$ & $1 / 3$ \\
\hline & Tertiary gross enrolment ratio & $2009-2014$ & $1 / 3$ \\
\hline NRI & 1. Network Use & 2002 & $1 / 2$ \\
\hline & 2. Enabling Factors & 2002 & $1 / 2$ \\
\hline & 2.1 Network Access & 2002 & $1 / 4$ \\
\hline & 2.2 Network Policy & 2002 & $1 / 4$ \\
\hline & 2.3 Networked Society & 2002 & $1 / 4$ \\
\hline & 2.4 Networked Economy & 2002 & $1 / 4$ \\
\hline & 3. Environment sub-index & $2003-2014$ & $1 / 3(2003-2011), 1 / 4$ (2012-2014) \\
\hline & 3.1 Market environment & $2003-2011$ & $1 / 3$ \\
\hline & 3.2 Infrastructure environment & $2003-2011$ & $1 / 3$ \\
\hline & 3.3 Political and regulatory environment & $2003-2014$ & $1 / 3(2003-2011), 1 / 2(2012-2014)$ \\
\hline & 3.4 Business and innovation environment & $2012-2014$ & $1 / 2$ \\
\hline & 4. Readiness sub-index & $2003-2014$ & $1 / 3(2003-2011), 1 / 4$ (2012-2014) \\
\hline & 4.1 Individual readiness & $2003-2011$ & $1 / 3$ \\
\hline & 4.2 Business readiness & $2003-2011$ & $1 / 3$ \\
\hline & 4.3 Government readiness & $2003-2011$ & $1 / 3$ \\
\hline & 4.4 Infrastructure and digital content & $2012-2014$ & $1 / 3$ \\
\hline & 4.5 Affordability & $2012-2014$ & $1 / 3$ \\
\hline & 4.6 Skills & $2012-2014$ & $1 / 3$ \\
\hline & 5. Usage sub-index & $2003-2014$ & $1 / 3(2003-2011), 1 / 4$ (2012-2014) \\
\hline & 5.1 Individual usage & $2003-2014$ & $1 / 3$ \\
\hline & 5.2 Business usage & $2003-2014$ & $1 / 3$ \\
\hline & 5.3 Government usage & $2003-2014$ & $1 / 3$ \\
\hline & 6. Impact sub-index & $2012-2014$ & $1 / 4$ \\
\hline & 6.1 Economic impacts & $2012-2014$ & $1 / 2$ \\
\hline & 6.2 Social impacts & $2012-2014$ & $1 / 2$ \\
\hline
\end{tabular}

Zdroj: Vlastní zpracování

\section{E-government Development Index}

První zpráva OSN, která se věnovala vývoji e-governmentu, vyšla v roce 2001 pod názvem Benchmarking E-government: A Global Perspective a představila první E-Government Index. Nicméně již další zpráva tento hodnotící rámec výrazně přepracovala a v roce 2003 tak byly představeny EGDI a EPI. Tyto zprávy hodnotí situaci vždy v předcházejícím roce nebo jiném časovém intervalu, např. v rozpětí 2-3 let. Od roku 2005 se začal telekomunikační sub-index přepočítávat na 100 obyvatel místo na 1000, což jen dokazuje větší rozšiřrení využívání těchto technologií mezi obyvatelstvem. Od roku 2008 se zvýšil význam (váha) mobilních telefonů. $\mathrm{V}$ průběhu let pak byly $\mathrm{z}$ rámce vyřazeny počty osobních počítačů a televizorů. $\mathrm{V}$ roce 2014 byl vůbec poprvé $\mathrm{v}$ jeho existenci pozměněn sub-index lidského kapitálu, což souvisí se stále se zvyšujícími požadavky sofistikovanějších ICT, zejména v oblasti bezpečnosti služeb. Vývoj tohoto indexu je zachycen na Obrázku 1, když rozpětí hodnot je na intervalu $0-1$, kde 1 znamená nejlepší. Členské státy EU jsou seřazeny podle nejlepší průměrné hodnoty ze všech měření. Rozdíly hodnot pro jednotlivé členské státy v průběhu let jsou značně nerovnoměrné, hledat nějaký lineární trend ve vývoji by bylo pravděpodobně značně obtížné. Dále je zde patrný značný pokles mezi roky 2008-2010, což bylo způsobeno důsledky globální krize. 
Obrázek 1: Vývoj indexu EGDI v letech 2003-2014 pro členské státy EU

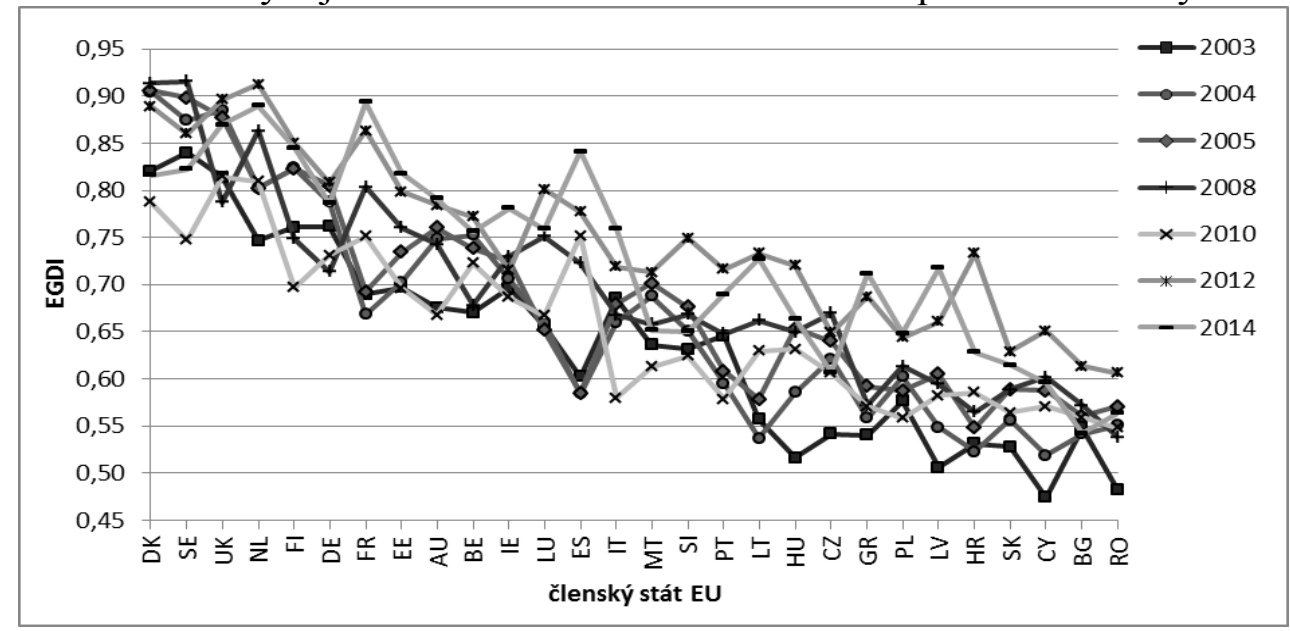

Zdroj: Vlastní zpracování

\section{ICT Development Index}

Předchůdci indexu IDI byly Digital Access Index (DAI) z roku 2003 a Digital Opportunity Index (DOI) z roku 2006. Žádný z těchto indexů se však již nedočkal pokračování. Až v roce 2009 byl představen IDI, který částečně vycházel z rámců těchto indexů. Ve stejné zprávě byl rovněž představen ICT Price Basket, který kombinuje tarify pro pevné linky, mobilní telefony a vysokorychlostní internet do jednoho ukazatele a porovnává ho relativně mezi sledovanými zeměmi na základě Hrubého národního př́jmu na obyvatele. Rámec tohoto indexu se za 6 let své existence výrazně neproměnil, pouze $\mathrm{v}$ roce 2013 byl prridán atribut pro bezdrátové vysokorychlostní připojení $\mathrm{k}$ internetu. Vývoj indexu $\mathrm{v}$ jednotlivých letech je zachycen na Obrázku 2, když rozpětí hodnot indexu je 1-10, kde 10 znamená nejlepší. Jak je z obrázku patrné, tak lze identifikovat kladné prírůstky hodnot indexu $\mathrm{v}$ jednotlivých měřených letech, pouze u států jižní Evropy je zřretelná stagnace mezi roky 2010-2013.

Obrázek 2: Vývoj indexu IDI v letech 2009-2014 pro členské státy EU

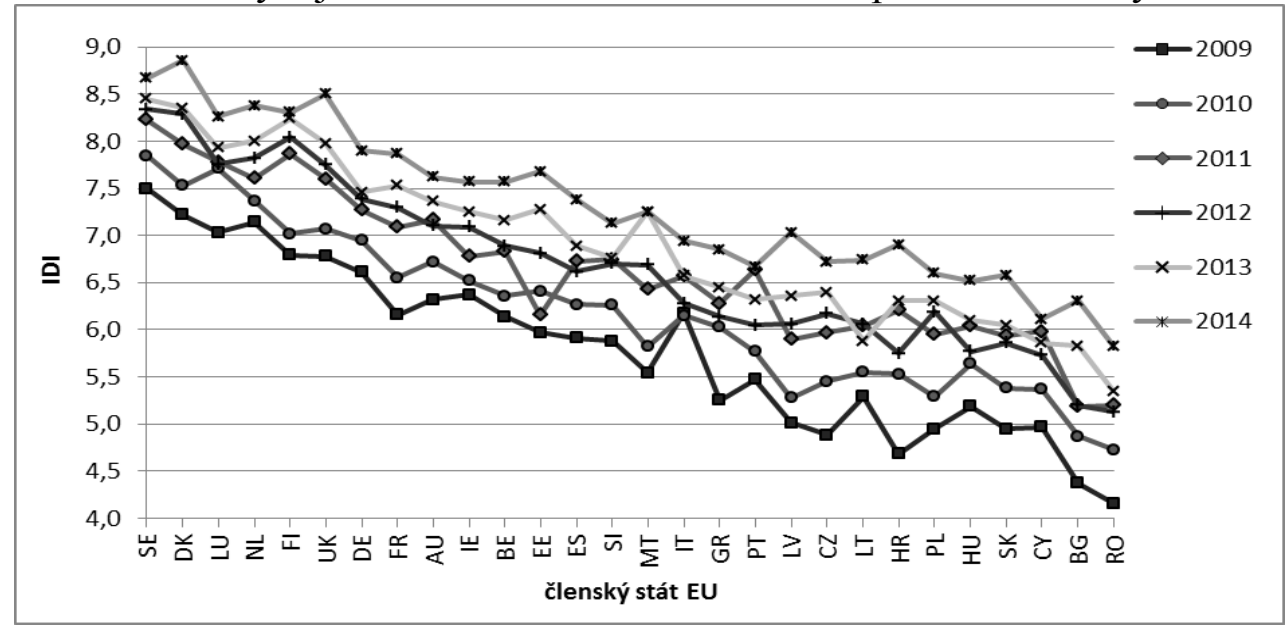

Zdroj: Vlastní zpracování

\section{Networked Readiness Index}

První zpráva WEF ze série The Global Information Technology Report vyšla v roce 2002. Nicméně již další rok byl rámec kompletně přepracován. Další výrazné změny přišly v roce 2012, kdy byl přidán sub-index ekonomických a sociálních dopadů a váhy ostatních indexů byly sníženy. Pokud se jedná o vývoj konkrétních atributů, které z důvodu přehlednosti nemohly být v předcházející tabulce 2 zmíněny, tak ty přibližně kopírují vývoj v oblasti ICT. 
V prvních letech bylo hodnoceno pokrytí televizním vysíláním, počet poruch telefonních linek, počet faxů, dostupnost a ceny mobilních telefonů, využívání e-mailu, apod. Po roce 2008 to byly atributy podporující mobilitu nebo rychlou dostupnost informací. Pro potřeby návrhu nového hodnotícího rámce jsou pak relevantní atributy představené $\mathrm{v}$ dalších letech využívání sociálních sítí, míra softwarového pirátství, dopad ICT na vznik nových produktů a služeb (všechny z roku 2011), modely B2B a B2C (2013) a další. Vývoj tohoto indexu je zachycen na Obrázku 3 (pro přehlednost jen v sudých letech), když rozpětí indexu je 1-7, kde 7 znamená nejlepší. Lucembursko a Chorvatsko jsou hodnoceny od roku 2003, Malta od roku 2004 a Kypr až od roku 2005. U tohoto indexu je patrná stagnace v průběhu sledovaných let, což může být způsobeno i tím, že rámec, resp. atributy tohoto indexu byly často měněny. To je zřejmě i prŕíčinou nadprůměrných hodnot v letech 2005 a 2006, a naopak podprůměrných hodnot pro rok 2004. Mezi lety 2008-2011 jsou i zde patrné vlivy globální ekonomické krize.

Obrázek 3: Vývoj indexu NRI v letech 2002-2014 pro členské státy EU

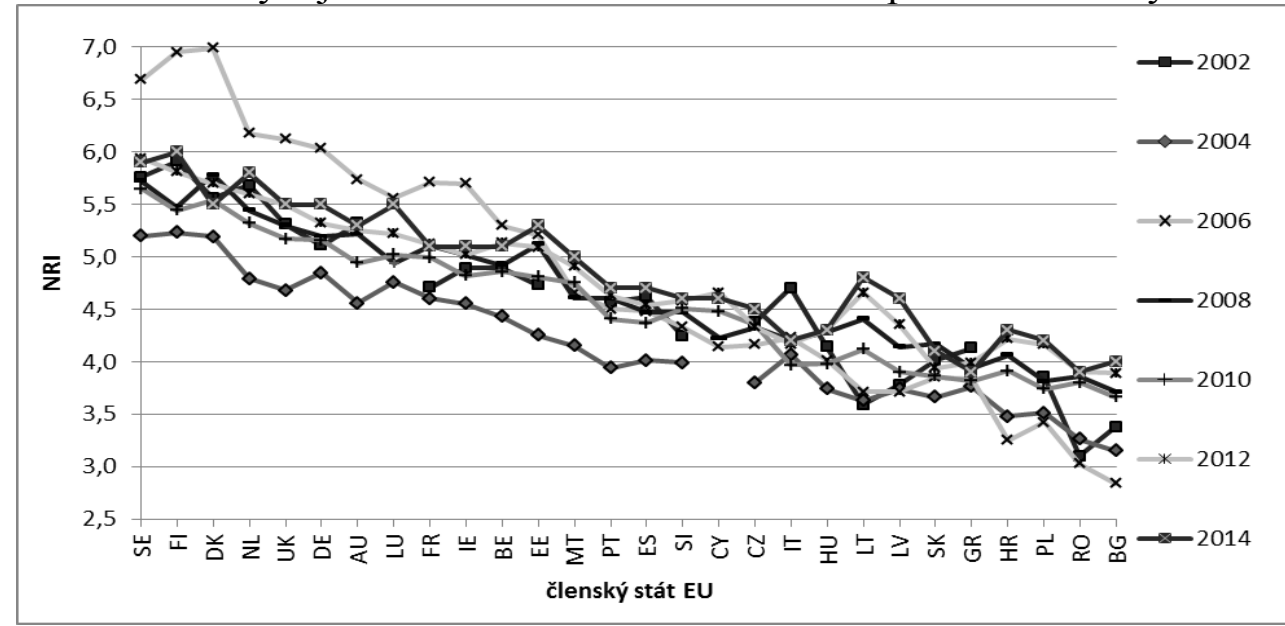

Zdroj: Vlastní zpracování

Na základě podrobné dekompozice struktury vybraných rámců první skupiny lze tvrdit, že ke změnám dochází zpravidla hned po představení nového indexu v jeho druhém nebo třetím roce, což je dáno zpětnou vazbou od zúčastněných stran. $\mathrm{K}$ dalším změnám struktury následně došlo v reakci na důsledky globální ekonomické krize, což dále potvrdilo i grafické zobrazení průběhu těchto vybraných indexů. Mezi členské státy EU s nejlepšími výsledky na základě výše porovnaných indexů patří - Švédsko, Dánsko, Nizozemsko a Spojené království.

\subsection{Popis vzniku a vývoje vybraných indexů druhé skupiny}

Vývoj struktury indexů, které patř́i do druhé skupiny, je zachycen v Tabulce 3. Z důvodu přehlednosti jsou opět zachyceny jen hlavní komponenty a jejich váhy. Konkrétní atributy či hodnotící otázky je možné nalézt ve zdrojových zprávách. Tyto indexy zpravidla nepokrývají všechny členské státy EU, proto zde nebude zachycen ani jejich vývoj v čase. 
Tabulka 3: Porovnání struktury druhé skupiny vybraných indexů v průběhu let

\begin{tabular}{|c|c|c|c|}
\hline Index & Struktura a sledované komponenty daného indexu & Pokrytí & Váha \\
\hline \multirow[t]{7}{*}{ BSA } & 1. Data Privacy & $2012-2013$ & $1 / 10$ \\
\hline & 2. Security & $2012-2013$ & $1 / 10$ \\
\hline & 3. Cybercrime & $2012-2013$ & $1 / 10$ \\
\hline & 4. Intellectual Property Rights & $2012-2013$ & $1 / 5$ \\
\hline & 5. Standards/International Harmonization of Rules & $2012-2013$ & $1 / 10$ \\
\hline & 6. Promoting Free Trade & $2012-2013$ & $1 / 10$ \\
\hline & 7. ICT Readiness, Broadband Deployment & $2012-2013$ & $3 / 10$ \\
\hline \multirow[t]{18}{*}{ CRI } & 1. Regulatory Conditions & 2011 & $1 / 10$ \\
\hline & 2. International Connectivity & $2011-2014$ & $1 / 10$ \\
\hline & 3. Data Protection Policy & 2011 & $1 / 10$ \\
\hline & 4. Broadband Quality & $2011-2014$ & $1 / 10$ \\
\hline & 5. Government Online Services and ICT Prioritization & $2011-2012$ & $1 / 10$ \\
\hline & 6. Power Grid Quality & 2011 & $1 / 10$ \\
\hline & 7. Internet Filtering & 2011 & $1 / 10$ \\
\hline & 8. Business Efficiency Index & 2011 & $1 / 10$ \\
\hline & 9. Global Risk & 2011 & $1 / 10$ \\
\hline & 10. ICT Development & 2011 & $1 / 10$ \\
\hline & 11. Intellectual Property Protection & $2012-2014$ & $1 / 10$ \\
\hline & 12. Freedom of Access to Information & $2012-2014$ & $1 / 10$ \\
\hline & 13. Data Sovereignty & $2012-2014$ & $1 / 10$ \\
\hline & 14. Data Privacy & $2012-2014$ & $1 / 10$ \\
\hline & 15. Data Centre Risk & $2012-2014$ & $1 / 10$ \\
\hline & 16. Power Grid and Green Policy & $2012-2014$ & $1 / 10$ \\
\hline & 17. Business Sophistication & $2012-2014$ & $1 / 10$ \\
\hline & 18. Government Regulatory Environment and Usage & 2014 & $1 / 10$ \\
\hline \multirow[t]{10}{*}{ GODI } & 1. Election Results & $2013-2014$ & $1 / 10$ \\
\hline & 2. Company Register & $2013-2014$ & $1 / 10$ \\
\hline & 3. National Map & $2013-2014$ & $1 / 10$ \\
\hline & 4. Government Spending & $2013-2014$ & $1 / 10$ \\
\hline & 5. Government Budget & $2013-2014$ & $1 / 10$ \\
\hline & 6. Legislation & $2013-2014$ & $1 / 10$ \\
\hline & 7. National Statistics & $2013-2014$ & $1 / 10$ \\
\hline & 8. Postcodes/Zipcodes & $2013-2014$ & $1 / 10$ \\
\hline & 9. Transport Timetables & $2013-2014$ & $1 / 10$ \\
\hline & 10. Pollutant Emissions & $2013-2014$ & $1 / 10$ \\
\hline \multirow[t]{10}{*}{ Waseda } & 1. Internet/Network Preparedness/Infrastructure & 2005-2014 & $\begin{array}{c}1 / 5(2005-2006), 1 / 6(2007-2010) \\
1 / 7(2011-2013), 1 / 20(2014) \\
\end{array}$ \\
\hline & $\begin{array}{l}\text { 2. Required Interface/Functioning Applications/Online } \\
\text { Services }\end{array}$ & 2005-2014 & $\begin{array}{c}1 / 5(2005-2006), 1 / 6(2007-2010) \\
1 / 7(2011-2013), 3 / 20(2014) \\
\end{array}$ \\
\hline & 3. Introduction of administrative applications and systems & $2005-2006$ & $1 / 5$ \\
\hline & 4. National Portal/Homepage & $2005-2014$ & $\begin{array}{c}1 / 5(2005-2006), 1 / 6(2007-2010) \\
1 / 7(2011-2013), 2 / 25(2014)\end{array}$ \\
\hline & $\begin{array}{l}\text { 5. Introduction of government Chief Information Officers } \\
\text { (CIO)/Government CIO }\end{array}$ & 2005-2014 & $\begin{array}{c}1 / 5(2005-2006), 1 / 6(2007-2010) \\
1 / 7(2011-2013), 3 / 25(2014) \\
\end{array}$ \\
\hline & 6. Management Optimization/Efficiency & $2007-2014$ & $\begin{array}{c}\text { 1/6 (2007-2010), 1/7 (2011-2013) } \\
3 / 25(2014)\end{array}$ \\
\hline & 7. e-Government Promotion & 2007-2014 & $\begin{array}{c}1 / 6(2007-2010), 1 / 7(2011-2013) \\
1 / 10(2014)\end{array}$ \\
\hline & 8. e-Participation/Digital Inclusion & $2011-2014$ & 1/7 (2011-2013), 1/10 (2014) \\
\hline & 9. Open Government & 2014 & $1 / 10$ \\
\hline & 10. Cyber Security & 2014 & $1 / 10$ \\
\hline \multirow[t]{7}{*}{$\begin{array}{c}\text { Web } \\
\text { index }\end{array}$} & 1. Communications and Institutional Infrastructure & 2012 & $1 / 5$ \\
\hline & 2. Web Content and Web Use & 2012 & $1 / 5$ \\
\hline & 3. Political, Economic and Social Impact & 2012 & $3 / 5$ \\
\hline & 4. Universal Access & $2013-2014$ & $1 / 4$ \\
\hline & 5. Freedom and Openness & $2013-2014$ & $1 / 4$ \\
\hline & 6. Relevant Content & $2013-2014$ & $1 / 4$ \\
\hline & 7. Empowerment & $2013-2014$ & $1 / 4$ \\
\hline
\end{tabular}

Zdroj: Vlastní zpracování 


\section{Business Software Alliance index}

Tento index byl představen v roce 2012 ve zprávě BSA Global Cloud Computing Scorecard: A Blueprint for Economic Opportunity a hodnotí různé oblasti ICT se zaměřením na cloud computing. Na začátku roku 2015 byly k dispozici dvě zprávy, když hodnotící rámec se prozatím nezměnil. Skládá se ze 7 kategorií, když každá z nich se dále skládá z několika hodnotících otázek nebo atributů (zpravidla 5-15) s různou váhou v rámci dané kategorie. V poslední kategorii tohoto indexu lze pak nalézt již známé indexy IDI a NRI nebo také IT industry competitiveness index a International Connectivity Score, jež jsou využívány jako jedny z hodnotících kritérií s nejvyšší váhou v rámci tohoto indexu.

\section{Cloud Readiness Index}

První zpráva od ACCA představující tento index vyšla v roce 2011, když zatím se dočkala dvou pokračování. Tento index hodnotí situaci v oblasti cloud computingu hlavně v asijských zemích, ale i v Austrálii a na Novém Zélandu. Kromě rámců pro hodnocení cloud computingu se ACCA věnuje i problematice open dat. Index CRI se skládá celkem z 10 komponent, když každá je dále tvořena dalšími atributy bud' přímo z průzkumů ACCA nebo od BSA, ITU a WEF. V roce 2012 byl pak index na základě zpětné vazby od zúčastněných stran výrazně přepracován a zároveň se od této doby člení do 3 neoficiálních kategorií - ochrana a regulace informací, informační infrastruktura, a podnikové a vládní prostředí, z čehož však vyplývá, že je zde zcela ignorován prvek občana, resp. zákazníka. Nejdůležitější kategorií je zde ochrana a regulace informací, která se skládá ze 4 komponent. Dủležitou roli v ní hraje $\mathrm{i}$ bezpečnost dat $\mathrm{v}$ cloudových úložištích.

\section{Global Open Data Index}

$\mathrm{V}$ roce 2013 byly poprvé porovnány vybrané země pomocí indexu GODI. Rámec tohoto indexu se prozatím nezměnil, je tvořen celkem 10 komponentami, když každá se dále skládá ze 6 technických hodnotících otázek definujících otevřenost dat s váhami 1/20,1/20,1/20, $3 / 20,1 / 10,1 / 10$ a 3 právních otázek s váhami 1/20,3/20 a 3/10. Tento index je prezentován jako pohled občana na dostupnost open dat veřejné správy. Ke každé hodnocené oblasti je zároveň dostupná i webová adresa, kde lze daná data nalézt.

\section{Waseda Index}

První hodnotící rámec tohoto indexu z roku 2005 se skládal z 5 komponent a 25 atributů. $\mathrm{V}$ průběhu let byl aktualizován $\mathrm{s}$ ohledem na vývoj $\mathrm{v}$ dané oblasti, když aktuální rámec $\mathrm{z}$ roku 2014 se skládá z 9 komponent a 33 atributů. Od roku 2014 je tento index prezentován jako vážený průměr, ale součet vah je pouze 0,92 . Vlastní rámec je aktualizován podle výsledků pravidelného dotazníkového šetření mezi vybranými experty, kteří rovněž definují pořadí nejdůležitějších trendů ve vývoji e-governmentu. Toto pořadí je rovněž součástí zpráv.

\section{Web Index}

Rámec tohoto indexu vznikl v roce 2012 jako reakce na využívání atributů jako např. počet uživatelů internetu, počty př́ipojek s vysokorychlostním připojením, atd. Hlavní myšlenkou toho rámce je tvrzení, že web je dnes tak významným nástrojem (akcelerátorem), že výrazně ovlivňuje sociální, ekonomický a politický vývoj země. První rámec z roku 2012 hodnotil pouze 3 oblasti (připravenost, web a dopad), které se skládaly z 34 atributů. Od následujícího roku pak využívá rámec, který se skládá z oblastí - př́istup, svoboda a otevřenost, relevantní obsah, a dopad, který hodnotí, jak mohou uživatelé užíváním webu podpořit pozitivní změny v těchto klíčových oblastech - společnost, hospodářství, politika a životní prostředí. 


\section{Literární rešerše}

Cílem této rešerše je určení trendů ve vývoji e-governmentu, které budou dále sloužit pro návrh vlastního hodnotícího rámce. Grönlund (2011) provedl výzkum, kde potvrdil, že státy a jejich výkonné orgány často využívají výše zmíněné indexy jako jeden z ukazatelů při rozhodování o investicích v oblasti e-governmentu. Členské státy EU pak již byly hodnoceny autory Siskos et al. (2013), kde byly státy seřazeny na základě 4 oblastí - infrastruktura, investice, e-procesy a prrístup uživatele. Nicméně byly zcela opomenuty nové trendy, jako je např. vliv vysokorychlostního připojení, cloud computingu, sociálních médií, apod.

Mohammed a Ibrahim (2013) analyzovali existující indexy e-governmentu, aby ukázali jejich společné komponenty a atributy $\mathrm{s}$ cílem návrhu vlastního rámce. Jejich rámec je založen na předpokladu, že výhody cloud computingu pro e-government zredukují potřebu některých požadavků (zdrojů). Ve výsledku budou mít některé atributy v rámci nižšśi váhu, např. ICT infrastruktura, která může být v cloudu, a jiné atributy budou nově představeny. Kurdi et al. (2011) navrhli rámec pro hodnocení připravenosti systémů e-governmentu se zaměřením na přechod $\mathrm{k}$ využívání cloud computingu. Jejich rámec pokrývá 4 oblasti - technologickou, organizační, obyvatele a zájmové skupiny, a životního prostředí a společnost. Také Alghamdi et al. (2011) navrhli rámec pro hodnocení ICT připravenosti v rozvojových zemích, který zdůraznil organizační hlediska v kontextu e-governmentu.

Krishnan et al. (2013) ukázali, že ICT infrastruktura, míra zapojování občanů do chodu státu a lidský kapitál mají př́mý vliv na úroveň (vývoj) e-governmentu. Liu a Wang (2010) pak použili metodu vícekriteriálního rozhodování, konkrétně Analytický Hierarchický Proces (Analytic Hierarchy Process, AHP) k tomu, aby navrhli hierarchický model s vybranými atributy, který aktérům $\mathrm{v}$ rozhodovacím procesu umožní výběr alternativy pro řešení daného problému na základě preferenčního pořadí. Yuming a Hongyan (2011) zase využili AHP k optimalizaci indexu EGDI. Jejich výsledky ukazují, že online elektronické služby jsou méně důležité pro rozvoj e-governmentu než telekomunikační infrastruktura nebo lidský kapitál. Mazengera a Mavetera (2011) použili korelační analýzu k tomu, aby identifikovali faktory, které jsou určující pro úspěšný rozvoj e-governmentu. Jejich studie prokázala, že existuje silná korelace mezi využíváním internetu, počtem mobilních telefonů a počtem telefonních linek, ale velmi nízká korelace s úrovní gramotnosti mezi dospělými. Sultan et al. (2012) navrhli vícekriteriální rozhodovací model za účelem výběru nejlepších prrístupů pro úspěšné nasazení projektů e-governmentu. Dále tvrdí, že lidské schopnosti, resp. související atributy, které je v modelu hodnotí, jsou těmi nejdůležitějšími pro rozvoj e-governmentu.

\section{Moderní ICT a aktuální trendy pro podporu rozvoje e-governmentu}

Určení aktuálních trendů vychází ze zpráv, které byly zmíněny výše. Daná problematika, resp. trend je pak často součástí i názvu dané zprávy. Vždy byly vybrány zprávy z posledních 5-6 let od těchto institucí - EU, ITU, OSN, WEF a Waseda University. Na základě porovnání struktury rámců vybraných indexů totiž bylo zjištěno, že k výraznějším změnám došlo po roce 2008 v reakci na globální ekonomickou krizi a znovu pak v roce 2012.

Určení hlavních trendů v EU vychází z hodnotících rámců - E-government Benchmarking 2010+ a E-government Benchmark Framework 2012-2015, na které jsou pak př́mo navázány zprávy EUBR. První rámec z roku 2009 řeší především oblast zapojování občanů do chodu státu, elektronické volby a měření úrovně základních elektronických služeb. Aktuální rámec pak zdůrazňuje jednotné centralizované portály, kde lze vybrané služby veřejné správy vyřš̌it plně elektronickou cestou, tzv. one-stop portály, cloud computing, open data, big data, služby zaměřené na uživatele, zelenou energii a úspory (European Commission, 2014). ITU od roku 
2009 zdůrazňuje význam mobilních telefonů pro př́stup $\mathrm{k}$ internetu, zvyšování dostupnosti vysokorychlostního internetu a internet do škol. Mezi roky 2010-2012 to bylo zvyšování uživatelů internetu, zlepšování nabídky elektronických služeb a také rovnoprávnost v př́stupu k internetu. Ve zprávě z roku 2013 pak lze nalézt doporučení pro využívání technologií cloud computingu, big data a multikanálové strategie, které využívají portály a sociální média pro komunikaci s občany. Pro rok 2014 by se mělo pokračovat v již zmíněných trendech, navíc byl přidán důraz na snižování cen připojení $\mathrm{k}$ internetu, kyberbezpečnost, zelené vládnutí a řešení problematiky elektroodpadu. Zásadní je rovněž právní rámec podporující zmíněné trendy (International Telecommunication Union, 2014).

Ve zprávě z roku 2010 OSN reaguje na globální ekonomickou krizi a zdůrazňuje význam zapojování občanů do rozhodovacích procesů veřejné správy na celonárodní i lokální úrovni. Dále je to dostupnost mobilních telefonů a kvalita vysokorychlostního připojení $\mathrm{k}$ internetu. Zároveň je zde poprvé blíže představena problematika open data. V roce 2012 a 2014 to jsou cloud computing, sociální média, m-government, chytré mobilní telefony, podpora vzdělávání $\mathrm{v}$ technických oborech a webové portály, u nichž je pak preferována dostupnost ve více jazycích (United Nations, 2014). WEF zpravidla nové trendy rychle zapracovává do svého hodnotícího rámce, což je dáno i tím, že je tvořen 50-60 atributy, což umožňuje rychlejší reakci. V roce 2010 byl ve zprávě zdůrazněn význam cloud computingu a vysokorychlostního připojení. V dalších letech přibyly sociální sítě, kyberbezpečnost a chytré mobilní telefony. $\mathrm{V}$ roce 2014 to jsou mobilní data, big data, portály pro open data a energetická efektivnost. Hlavní důraz by měl být ale kladen na digitální obsah, jeho dostupnost, kvalitu a bezpečnost, tzn. ochrana duševního vlastnictví (World Economic Forum, 2014). V roce 2009 byly podle zprávy od Waseda University hlavními trendy reforma veřejné správy, nové elektronické služby a zapojování občanů do chodu státu. V následujících letech to byl m-government, zelené vládnutí a úspory energie, tvorba centralizovaných portálů s nabídkou elektronických služeb, vysokorychlostní připojení $\mathrm{k}$ internetu a jeho větší dostupnost. V roce 2011 se do popředí dostala sociální média. Od roku 2012 až doposud je na prvním místě uváděn cloud computing. Dále to jsou open a big data, kyberbezpečnost a problémy se stárnoucí populací. V roce 2014 byla přidána interoperabilita a lokální e-government (Waseda University, 2014).

Na základě těchto trendů, literární rešerše a podrobné analýzy struktury vybraných indexů byly vybrány tyto trendy, které budou využity při návrhu vlastního hodnotícího rámce:

- cloud computing - využívání těchto technologií je výhodné především z důvodů snižování nákladů, centrálního pronájmu služeb na různých úrovních veřejné správy, zálohování dat v cloudových úložištích, apod.,

- open data a big data - oba pojmy spolu úzce souvisí, lze nalézt i termín open big data, jedná se zejména o dostupnost datových sad, členěných na základě kategorií, které jsou zdarma dostupná na různých portálech,

- sociální média - jejich využívání pro komunikaci s občany, předávání informací nebo prezentaci nových služeb,

- vysokorychlostní připojení k internetu s vyšší váhou pro bezdrátové připojení, které je v současnosti preferovanější,

- multikanálové portály veřejné správy - zejména portály veřejné správy, možnosti elektronických služeb a jejich vyřízení online, apod.,

- zapojování občanů do rozhodovacích procesů ve veřejné správě,

- schopnosti a podpora vzdělávání zejména v technických oborech,

- bezpečnost a ochrana informací,

- zelené vládnutí a energetická efektivnost. 


\section{Návrh nového rámce pro hodnocení vývoje e-governmentu}

Nový rámec, který je zachycen $\mathrm{v}$ Tabulce 4 vychází ze struktury výše porovnaných rámců, které doplňuje o aktuální trendy. Rámec byl již představen ve Lněnička et al. (2015), nicméně na základě zpětné vazby byl výrazně přepracován. Hlavní změny spočívaly v redukci počtu sub-indexů z 8 na 7 a také počtu atributů z původních 46 na 34. Zároveň byl zvýšen význam bezpečnosti a ochrany informací, ICT připravenosti občanů a podniků, a byly nově přidány atributy, které hodnotí konkrétní dopady open dat, big dat, energetické efektivnosti a zeleného vládnutí. Autoři tak těmito změnami navazují na myšlenku, ze které vychází např. Web Index. Tato myšlenka nebo také př́stup k návrhu rámce vychází z trendu, kdy komunikace a výměna informací mezi jednotlivými zúčastněnými stranami dnes probíhá zejména na webu. Nejedná se již pouze o využívání elektronických služeb veřejné správy, ale o využívání moderních ICT nástrojů a komunikačních prostředků jako např. sociální média, aplikace vytvářené nad open daty, multikanálové kampaně, m-government, apod. Nicméně i přes nesporný význam těchto technologií je struktura nového rámce i nadále tvořena ověřenými atributy, které byly určeny na základě dekompozice vybraných indexů. Nové trendy je však vhodně doplňují a pomáhají zachovat kontinuitu vývoje hodnotících rámců pro měření rozvoje e-governmentu.

Vlastní hodnotící rámec se tedy člení na sub-indexy, v rámci kterých lze vybrané státy rovněž porovnávat. Každý atribut má svoji váhu v rámci sub-indexu, který má dále vlastní váhu vůči celému indexu. První sub-index vymezuje politické a legislativní prostředí rámce. Druhý má ze všech sub-indexů největší váhu (význam) a je tvořen částí hodnotící připravenost občanů a částí, která hodnotí připravenost podniků. U občanů je důraz kladen na terciární vzdělávání se zaměřením na matematické vzdělání a míru zapojování do rozhodování státu. U podniků je hodnocena jejich globální konkurenceschopnost a jejich př́stup k nejnovějším technologiím. Další sub-index hodnotí ICT infrastrukturu a dostupnost připojení k internetu se zaměřením na bezdrátové vysokorychlostní připojení. Následuje sub-index online elektronických služeb, kde jsou hodnoceny jen služby vyšší úrovně (zralosti). Pátý sub-index je zaměřen na zajištění bezpečnosti a ochrany informací při jejich výměně a komunikaci mezi jednotlivými stranami. Poslední dva sub-indexy hodnotí dopad těchto nových technologií na různé oblasti. U nich se předpokládá, že mohou být ještě mírně upraveny. 
Tabulka 4: Nový rámec pro hodnocení vývoje e-governmentu

\begin{tabular}{|c|c|c|c|}
\hline Sub-index & Atributy & Zdroj dat & Váha [\%] \\
\hline \multicolumn{3}{|c|}{ 1. Index politického a legislativního prostředí } & 15 \\
\hline & 1.1 Zákony související s ICT & WEF & 25 \\
\hline & 1.2 Využívání ICT a vládní efektivnost & WEF & 20 \\
\hline & 1.3 Dostupnost digitálního obsahu & WEF & 20 \\
\hline & 1.4 Blokování / filtrování obsahu na webu & W3F & 20 \\
\hline & 1.5 Existence rámce nebo strategie pro cloud computing & vlastní & 15 \\
\hline \multicolumn{3}{|c|}{ 2. Index ICT připravenosti občanů a podniků } & 20 \\
\hline & \multicolumn{2}{|l|}{ Občané } & 55 \\
\hline & 2.1 Gramotnost dospělých & UNESCO & 20 \\
\hline & 2.2 Hrubá míra školní docházky - terciární vzdělávání & UNESCO & 20 \\
\hline & 2.3 Kvalita matematického a vědeckého vzdělávání & WEF & 25 \\
\hline & 2.4 Využivání sociálních sítí & WEF & 15 \\
\hline & 2.5 Míra zapojování obyvatel do rozhodování státu (index EPI) & OSN & 20 \\
\hline & \multicolumn{2}{|l|}{ Podniky } & 45 \\
\hline & 2.6 Index globální konkurenceschopnosti & WEF & 35 \\
\hline & 2.7 Dostupnost nejnovějších technologií & WEF & 35 \\
\hline & 2.8 Vládní zakázky na vyspělé technologické produkty & WEF & 30 \\
\hline \multicolumn{3}{|c|}{ 3. Index ICT infrastruktury a dostupnosti připojení $\mathrm{k}$ internetu } & 15 \\
\hline & 3.1 Pevné vysokorychlostní připojení $\mathrm{k}$ internetu na 100 obyvatel & ITU & 15 \\
\hline & 3.2 Bezdrátové vysokorychlostní připojení $\mathrm{k}$ internetu na 100 obyvatel & ITU & 25 \\
\hline & 3.3 Mobilní telefony na 100 obyvatel & ITU & 20 \\
\hline & 3.4 Procento jednotlivců využívajících internet & ITU & 25 \\
\hline & 3.5 Mezinárodní rychlost připojení (bit/s) na internetového uživatele & ITU & 15 \\
\hline \multicolumn{3}{|c|}{ 4. Index online elektronických služeb } & 15 \\
\hline & 4.1 Dopad ICT na nové služby a produkty & WEF & 35 \\
\hline & 4.2 Úroveň (zralost) 3 pro elektronické služby & OSN & 30 \\
\hline & 4.3 Úroveň (zralost) 4 pro elektronické služby & OSN & 35 \\
\hline \multicolumn{3}{|c|}{ 5. Index bezpečnosti a ochrany informací } & 15 \\
\hline & 5.1 Ochrana duševního vlastnictví & WEF & 25 \\
\hline & 5.2 Existence zákona o elektronickém podpisu & vlastní & 30 \\
\hline & 5.3 Účinná právní ochrana před počítačovou kriminalitou & W3F & 25 \\
\hline & 5.4 Bezpečné internetové servery na jeden milion obyvatel & Světová banka & 20 \\
\hline \multicolumn{3}{|c|}{ 6. Index pro open data, big data a jejich dopad } & 10 \\
\hline & 6.1 Open data a jejich dostupnost (index GODI) & OKF & 20 \\
\hline & 6.2 Existence národního portálu pro open a big data & vlastní & 20 \\
\hline & 6.3 Existence legislativy pro interoperabilitu a přenositelnost dat & vlastní & 20 \\
\hline & 6.4 Open data a jejich dopad na transparentnost a odpovědnost & W3F & 20 \\
\hline & 6.5 Open data a jejich dopad na rozvoj nových podniků & W3F & 20 \\
\hline \multicolumn{3}{|c|}{ 7. Index energetické efektivnosti a zeleného vládnutí } & 10 \\
\hline & $\begin{array}{l}\text { 7.1 Využívání ICT s cílem zvýšit povědomí o životním prostředí a } \\
\text { změnách v životním stylu }\end{array}$ & W3F & 25 \\
\hline & 7.2 Dopad kampaní a akcí souvisejících s životním prostředím & W3F & 20 \\
\hline & 7.3 Index výkonnosti životního prostředí & Yale University & 25 \\
\hline & 7.4 Index výkonnosti energetické architektury & WEF & 30 \\
\hline
\end{tabular}

Zdroj: Vlastní zpracování

Výstupem tohoto rámce je index, který bude představen v dalších příspěvcích. Aktuální data pro jednotlivé atributy lze získat z veřejně dostupných zdrojů (sekundární data), kromě 4 vlastních atributů, které jsou hodnoceny jako ano / ne, resp. 0 / 1 pro potřeby výpočtu indexu. Nejprve budou data standardizována tak, aby výsledky nebyly závislé na různých jednotkách měření, a následně bude index normalizován na interval $0-1$, kde 1 znamená nejlepší možný výsledek. I tento rámec bude nejdříve vypočítán a porovnán pro členské státy EU.

\section{Závěr}

Poslední dvě desetiletí byly ve světě ve znamení výrazného růstu odvětví ICT, související infrastruktury a služeb. Zároveň se vyvíjely i rámce pro hodnocení rozvoje e-governmentu. Počátky hodnocení e-governmentu ve vybraných zemích světa lze zasadit do období konce 90. let minulého století a začátku nového tisíciletí. Na počátku se hodnotily počty televizorů 
nebo minimálně existence národní portálu. Postupně se dostaly do popředí pevné telefonní linky a vytáčené připojení, které byly postupně nahrazeny mobilními telefony a bezdrátovým připojením $\mathrm{k}$ internetu. Zároveň $\mathrm{s}$ dostupností se zvyšovala i rychlost tohoto připojení. Velmi důležitým zjištěním je, že většina rámců byla výrazně přepracována hned ve druhém nebo dalším období, z čehož vyplývá, že důležitým prvkem návrhu vlastního rámec je zpětná vazba od zasažených subjektů, př́ipadně nezávislých pozorovatelů. Další změny lze najít mezi roky 2008 a 2012 v návaznosti na globální ekonomickou krizi. V posledních letech se do popředí začaly dostávat nové trendy jako cloud computing, open data, big data, sociální média, vyšší míra zapojení občanů do rozhodovacích procesů, zelené vládnutí a úspory energie, apod.

Proto byl $\mathrm{v}$ tomto příspěvku navržen nový hodnotící rámec, který má za cíl zachytit vlivy těchto trendů ve vývoji e-governmentu. V další fázi budou vypočítány konkrétní hodnoty pro nový rámec a vybrané státy budou porovnány na základě reálných hodnot. Pokud se jedná o podporu nových trendů, tak většina globálních zpráv se shoduje na tom, že nejprve je nutné vytvořit odborné skupiny, různé metodiky, vybrané technologie testovat, a pokud je to možné, tak vycházet $\mathrm{z}$ těchto výsledků (best practices) a řešení implementovat na celonárodní úrovni.

\section{Literatura}

[1] ALGHAMDI, I. A., R. GOODWIN a G. RAMPERSAD, 2011. E-Government Readiness Assessment for Government Organizations in Developing Countries. Computer and Information Science, 4(3), 3-17. ISSN 1913-8997.

[2] EUROPEAN COMMISSION, 2014. Delivering the European Advantage?: The 11th eGovernment Benchmark report. Luxembourg: Publications Office of the European Union. ISBN 978-92-79-38052-5.

[3] GRÖNLUND, Å., 2011. Connecting eGovernment to Real Government - The Failure of the UN eParticipation Index. In: Proceedings of the 10th IFIP WG 8.5 International Conference: EGOV 2011. Berlin: Springer, s. 26-37. ISBN 978-3-642-22877-3.

[4] INTERNATIONAL TELECOMMUNICATION UNION, 2014. Measuring the Information Society Report 2014. Geneva: Telecommunication Development Bureau. ISBN 978-92-61-15291-8.

[5] KRISHNAN, S., T. TEO a J. LIM, 2013. E-Participation and E-Government Maturity: A Global Perspective. In: Grand Successes and Failures in IT: Public and Private Sectors. Berlin: Springer, s. 420-435. ISBN 978-3-642-38862-0.

[6] KURDI, R., A. TALEB-BENDIAB, M. RANDLES a M. TAYLOR, 2011. EGovernment Information Systems and Cloud Computing (Readiness and Analysis). In: Proceedings of the 2011 International Conference on Developments in eSystems Engineering. IEEE, s. 404-409. ISBN 978-1-4577-2186-1.

[7] LIU, J. a S. WANG, 2010. A Study on Multi-objective Optimization of E-Government Based on AHP. In: Proceedings of the 2010 International Conference on Electrical and Control Engineering. IEEE, s. 2643-2646. ISBN 978-1-4244-6880-5

[8] LNĚNIČKA, M., R. MÁCHOVÁ a J. KOMÁRKOVÁ, 2015. Cloud E-Government Index as a New Benchmarking Framework for the Public Sector. In: Proceedings of the 19th International Conference Current Trends in Public Sector Research. Brno: Masaryk University, s. 29-37. ISBN 978-80-210-7532-0.

[9] MAZENGERA, B a N. MAVETERA, 2011. Factors Contributing To Successful EGovernment Implementation in Southern African Development Community (SADC) 
Countries. In: Proceedings of the 16th IBIMA Conference on Innovation and Knowledge Management. Kuala Lumpur, Malaysia: IBIMA Publishing, s. 1050-1057. ISBN 978-09821489-5-2.

[10] MOHAMMED, F. a O. IBRAHIM, 2013. Refining E-government Readiness Index by Cloud Computing. Jurnal Teknologi, 65(1), 23-34. ISSN 0127-9696.

[11] RORISSA, A., D. DEMISSIE a T. PARDO, 2011. Benchmarking e-Government: A comparison of frameworks for computing e-Government index and ranking. Government Information Quarterly, 28(3), 354-362. ISSN 0740-624X.

[12] SISKOS, E., M. MALAFEKAS, D. ASKOUNIS a J. PSARRAS, 2013. E-government Benchmarking in European Union: A Multicriteria Extreme Ranking Approach. In: Proceedings of the 12th IFIP WG 6.11 Conference on e-Business, e-Services, and eSociety (I3E 2013). Berlin: Springer, s. 338-348. ISBN 978-3-642-37437-1.

[13] SUlTAN, A., K. A. ALARFAJ a G. A. ALKUTBI, 2012. Analytic Hierarchy Process for the success of e-government. Business Strategy Series, 13(6), 295-306. ISSN 17515637.

[14] UNITED NATIONS, 2014. United Nations e-Government Survey 2014: E-Government for the Future We Want. New York: UN Publishing Section. ISBN 978-92-1-123198-4.

[15] WASEDA UNIVERSITY, 2014. WASEDA - IAC 10th International E-Government Ranking 2014. Tokyo: Waseda University. Dostupné z: http://www.egov.waseda.ac.jp/pdf/2014_E-Gov_Press_Release.pdf

[16] WORLD ECONOMIC FORUM, 2014. The Global Information Technology Report 2014: Rewards and Risks of Big Data. Geneva: SRO-Kundig. ISBN 978-92-95044-63-0.

[17] YUMING, W. a L. HONGYAN, 2011. Optimization for Weight Design of the EGovernment Development. In: Proceedings of the 7th International Conference on Wireless Communications, Networking and Mobile Computing (WiCOM). IEEE, s. 1-4. ISBN 978-1-4244-6251-3. 